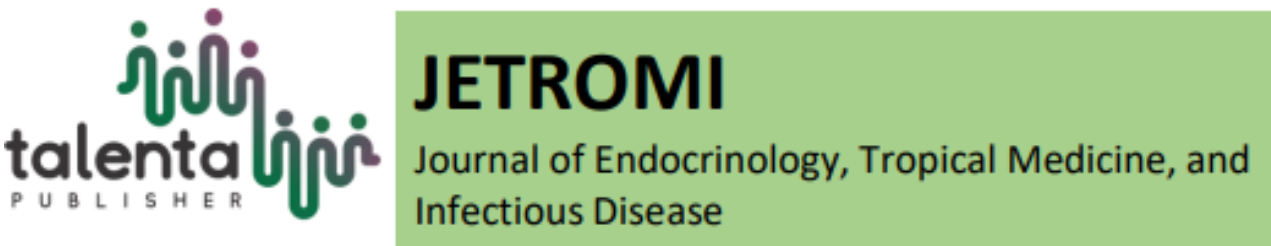

\title{
Correlation between Lipid Profile and D-dimer of Covid-19 Patients with Type 2 Diabetes Mellitus
}

\author{
Annisa Nidya Rahmatika Sitepu*, Melati Silvanni Nasution \\ Department of Internal Medicine, Faculty of Medicine, Universitas Sumatera Utara, Medan, North \\ Sumatera, Indonesia
}

\begin{abstract}
.
Background. Lipids play a central role in viral infection, as they represent the structural foundations of cellular and viral membranes. The study aimed to examine the relationship between the D-dimer of T2DM patients with the lipid profile parameters of newly diagnosed COVID-19 patients.

Method. This study uses secondary data, which is obtained from medical records of $\mathrm{H}$. Adam Malik Medan Hospital between 2020-2021. The population of this study was all inpatients confirmed COVID-19 through RT-PCR SARS-CoV-2 swab examination.

Results. There are 163 participants in this study. HbA1c values were high in T2DM patients with Covid-19, while lipid, and D-dimer profile values were still normal. Parameter of $\mathrm{HbA1c}$, lipid and D-dimer profiles between men and women do not differ significantly. Ddimer is not correlated with $\mathrm{HbA1c}$ parameters and lipid profiles

Conclusion. In this study, HbA1c values were high in T2DM patients with Covid-19, while D-dimer is not correlated with $\mathrm{HbA1c}$ parameters and lipid profiles

Keywords. SARS-CoV-2; COVID-19; Diabetes Mellitus; D-dimer; Lipid profile

Abstrak.

Latar belakang. Lipid memainkan peran sentral dalam infeksi virus, karena lipid merupakan dasar struktural membran seluler dari virus. Tujuan dari penelitian ini adalah untuk meneliti hubungan antara D-dimer dari pasien T2DM dengan parameter profil lipid pasien COVID19 yang baru didiagnosis.

Metode. Penelitian ini menggunakan data sekunder, yang diperoleh dari rekam medis RSUP H. Adam Malik Medan antara tahun 2020-2021. Populasi penelitian ini adalah semua pasien rawat inap yang dikonfirmasi COVID-19 melalui pemeriksaan swab RT-PCR SARS-CoV-2. Hasil. Ada 163 peserta dalam penelitian ini. Nilai HBAlc adalah tinggi pada pasien T2DM dengan Covid-19, sementara nilai profil lipid dan D-dimer masih normal. Parameter profil $H b A l c$, lipid dan D-dimer antara pria dan wanita tidak berbeda secara signifikan. D-dimer tidak berkorelasi dengan parameter HbAlc dan profil lipid

Kesimpulan. Nilai HbAlc tinggi pada pasien T2DM dengan Covid-19, sementara D-dimer tidak berkorelasi dengan parameter HbAlc dan profil lipid.

Kata Kunci. SARS-CoV-2; COVID-19; Diabetes Mellitus; D-dimer; Profil lipid
\end{abstract}

\footnotetext{
*Corresponding author at Department of Internal Medicine, Faculty of Medicine, University of Sumatera Utara, Medan, North Sumatera, Indonesia

E-mail address: annisa.nidya94@gmail.com
} 


\section{Introduction}

The rapidly growing Coronavirus Disease (COVID-19) pandemic represents a serious global challenge.[1] The emergence of SARS-CoV-2 has been manifested as the third revelation of a highly pathogenic coronavirus into the human population after the severe acute respiratory syndrome coronavirus (SARS-CoV) in 2002 and the Middle East Respiratory Syndrome coronavirus (MERS-CoV) in 2012.[2,3] The factors that influence the survival of such viruses on various surfaces depend on several factors such as the viral load, type of surface, suspension medium, humidity, temperature, and others.[4]

Following COVID-19 infection, SARS-CoV-2 can penetrate the mucous membranes of the nose, eye, and/or mouth and move on to other vital organs such as the lung. Infections with SARS$\mathrm{CoV}-2$ range from asymptomatic or mild infections restricted to the upper respiratory tract to severe respiratory syndromes manifested by disseminated spread to the lower airways leading to local inflammation and pneumonia, especially in patients with comorbidities such as diabetes, hypertension, and cardiovascular disease (CVD).[5] People with diabetes mellitus (DM), severe obesity, and hypertension are more prone to be infected and are at a higher risk for complications and mortalities from COVID-19.[6]

Lipids play a central role in viral infection, as they represent the structural foundations of cellular and viral membranes.[7] Viruses attack lipid synthesis and signaling to modify host cells to produce lipids for their envelopes. Lipid involvement in membrane fusion, envelopment, and transformation are important for viral replication, and molecules that impact lipids such as cholesterol and sphingolipids could be targeted to selectively impede viral replication. Viruses replicate within the host cell; hence, they must cross the host cellular membrane for entry and exit.[7]

Dyslipidemia is associated with damage to the immune, respiratory, and cardiovascular systems, along with high levels of proinflammatory cytokines. Furthermore, dyslipidemia is casually associated with an increased risk of thrombotic complications, endothelial dysfunction, and a higher platelet activity.[8] Thus, lipid dysregulation may contribute to morbidity and mortality from COVID-19 infection. However, the characteristics and dynamic changes in lipid profiles in COVID-19 patients, as well as their predictive value in disease severity and mortality, remain largely unknown. Compared with mild or asymptomatic COVID-19 patients, individuals with severe complications have higher prevalence of comorbidities such as hypertension, cardiovascular disease and type 2 diabetes mellitus (T2DM).[9] These comorbidities share the common metabolic alterations of insulin resistance and dyslipidemia; the latter has been linked to severe COVID-19 by Choi et al.[10] and Hariyanto et al.[11] 
The study aimed was to examine the relationship between the D-dimer of T2DM patients and the lipid profile parameters of newly diagnosed COVID-19 patients.

\section{Method}

This study uses secondary data, which is obtained from medical records of H. Adam Malik Medan Hospital between 2020-2021. The population of this study was all inpatients confirmed COVID19 through an RT-PCR SARS-CoV-2 swab examination. The study sample was obtained by the total sampling method, where all populations that meet the criteria of inclusion and exclusion are used as research samples. Inclusion criteria, all inpatients with T2DM confirmed COVID-19 and aged $\geq 18$ years. Exclusion criteria of patients with incomplete medical record data. Patients were triaged as per severity on basis of national guidelines: asymptomatic, Mild (respiratory rate < 24/min, $\mathrm{SpO} 2>94 \%$ at room air), moderate (respiratory rate: $24-30 / \mathrm{min}, \mathrm{SpO} 2$ 90-94\% at room air) and severe (respiratory rate $>30 /$ min $\mathrm{SpO} 2<90 \%$ ), ARDS and septic shock.[6] HbA1c implementation using HPLC methods, D-dimer, and CRP is measured by the ELISA method.

Data univariate analysis is presented descriptively, displaying average data and standard deviations. Test normality of data using the Shapiro Wilk test. The bivariate analysis uses a Tindependent test if data is distributed abnormally. If data is not distributed normally used the Mann-Whitney test. Test Pearson correlation when distributed data is normal, and use spearman correlation if data is not distributed normally. Analysis using computer programs SPSS (Statistical Product and for Social Sciences) and confidence intervals of 95\%, where $\mathrm{p}<0.05$ considered significant.

\section{Result}

In table 1, There are 163 participants in this study. HbA1c values were high in T2DM patients with Covid-19, while lipid and D-dimer profile values were still normal.

Table 1 Baseline data of T2DM with COVID-19

\begin{tabular}{lc}
\hline Parameter & $\bar{x} \pm \mathbf{S D}, \mathbf{n}=\mathbf{1 6 3}$ \\
\hline $\mathrm{HbA} 1 \mathrm{c}, \%$ & $9.5 \pm 2.4$ \\
$\mathrm{TC}, \mathrm{mg} / \mathrm{dl}$ & $166 \pm 45.4$ \\
$\mathrm{TG}, \mathrm{mg} / \mathrm{dl}$ & $164.6 \pm 100.3$ \\
$\mathrm{HDL}-\mathrm{C}, \mathrm{mg} / \mathrm{dl}$ & $31.8 \pm 11.8$ \\
$\mathrm{LDL}-\mathrm{C}, \mathrm{mg} / \mathrm{dl}$ & $107.1 \pm 38.2$ \\
$\mathrm{CRP}, \mathrm{mg} / \mathrm{L}$ & $0.9 \pm 0.5$ \\
D-dimer, $\mu \mathrm{g} / \mathrm{L}$ & $284.1 \pm 266.2$
\end{tabular}

TC: total cholesterol; TG: triglyceride; HDL-C: high-density lipoprotein cholesterol; LDLC: low-density lipoprotein cholesterol; CRP: C-Reactive Protein

On table 2, the parameter of HbA1c, lipid, and D-dimer profiles between men and women do not differ significantly. 
Table 2 Parameter of HbA1c, lipid and D-dimer profiles between men and women

\begin{tabular}{lccc}
\hline \multicolumn{1}{c}{ Parameter } & Man & Woman & $\mathrm{P}$ \\
& $\bar{x} \pm \mathrm{SD}, \mathrm{n}=92$ & $\bar{x} \pm \mathrm{SD}, \mathrm{n}=71$ & \\
\hline HbA1c, $\%$ & $9.5 \pm 2.3$ & $9.4 \pm 2.5$ & 0.961 \\
TC, $\mathrm{mg} / \mathrm{dl}$ & $165.8 \pm 46.2$ & $166.9 \pm 44.6$ & 0.880 \\
TG, $\mathrm{mg} / \mathrm{dl}$ & $170.9 \pm 106.0$ & $156.5 \pm 92.7$ & 0.367 \\
HDL-C, $\mathrm{mg} / \mathrm{dl}$ & $32.4 \pm 11.8$ & $31.0 \pm 11.8$ & 0.467 \\
LDL-C, $\mathrm{mg} / \mathrm{dl}$ & $105.4 \pm 392$ & $109.2 \pm 36.9$ & 0.528 \\
CRP, $\mathrm{mg} / \mathrm{L}$ & $1.0 \pm 0.5$ & $0.9 \pm 0.4$ & 0.715 \\
D-dimer, $\mu \mathrm{g} / \mathrm{L}$ & $275.5 \pm 252.0$ & $295.2 \pm 284.6$ & 0.640 \\
\hline
\end{tabular}

TC: total cholesterol; TG: triglyceride; HDL-C: high-density lipoprotein cholesterol; LDLC: low-density lipoprotein cholesterol; CRP: C-Reactive Protein

On table 3, D-dimer is not correlated with HbA1c parameters and lipid profiles

Table 3 Correlation between $\mathrm{HbA1c}$ parameter with $\mathrm{HbA1c}$ parameter and lipid profile

\begin{tabular}{lcc}
\hline Parameter & $\mathrm{r}$ & $\mathrm{p}$ \\
\hline HbA1c, $\%$ & 0.019 & 0.400 \\
TC, mg/dl & -0.013 & 0.433 \\
TG, mg/dl & -0.061 & 0.219 \\
HDL-C, mg/dl & -0.089 & 0.131 \\
LDL-C, mg/dl & 0.055 & 0.249 \\
CRP, mg/L & -0.005 & 0.476 \\
\hline
\end{tabular}

TC: total cholesterol; TG: triglyceride; HDL-C: high-density lipoprotein cholesterol; LDLC: low-density lipoprotein cholesterol; CRP: C-Reactive Protein

\section{Discussion}

SARS-COV-2 is an enveloped virus that is surrounded by a lipid bilayer. Lipids are fundamental cell components that play various biological roles ranging from being a structural building block to a signaling molecule as well as a central energy store. The role lipids play in viral infection involves the fusion of the viral membrane to the host cell, viral replication, and viral endocytosis and exocytosis. Since lipids play a crucial function in the viral life cycle, we asked whether drugs targeting lipid metabolism, such as statins, can be utilized against SARS-CoV-2 and other viruses.[12] Virally infected cells seem to require higher metabolic alterations to deal with the high anabolic demands required during viral replication.[13] Virion production requires a rearrangement of the entire biosynthesis apparatus, a process that usually involves major changes in the cellular lipidome. Nonetheless, there are highly exclusive patterns of virus-induced remodeling of host cell metabolic machinery, and the mode of cell manipulation appears to be different between DNA and RNA viruses.[13]

Lipids can act as direct receptors or entry co-factors for all types of viruses at the cell surface or the endosomes.[14] They also play an important role in the formation and function of the viral replication complex, as well as the generation of the energy required for efficient viral replication.[13] Moreover, lipids can regulate the appropriate cellular distribution of viral proteins, in addition to the assembly, trafficking, and release of viral particles.[15] Coronaviruses firstly seize host cell intracellular membranes to create new compartments known as doublemembrane vesicles (DMVs) needed for viral genome amplification. A specific phospholipid 
composition is required by different viruses to form the perfect replicative organelles that are suitable for their replication.[16] DMVs are membranous structures that contain viral proteins and an array of confiscated host factors, which jointly orchestrate an exclusive lipid microenvironment.

In this study, in men and women patients with T2DM and COVID-19, there was no significant difference in $\mathrm{HbA1c}$, lipid profile, CRP, and D-dimer. D-dimers are not correlated with $\mathrm{HbA1c}$, lipid profile, and CRP. All T2DM patients are newly diagnosed patients with COVID-19, so there has been no change in inflammatory signs.

\section{Conclusion}

In this study, HbA1c values were high in T2DM patients with Covid-19, while D-dimer is not correlated with HbA1c parameters and lipid profiles

\section{REFERENCES}

[1] Walls, A.C.; Park, Y.J.; Tortorici, M.A.; Wall, A.; McGuire, A.T.; Veesler, D. Structure, Function, and Antigenicity of the SARS-CoV-2 Spike Glycoprotein. Cell 2020. 2020 Apr 16,vol.18, no.2:p.281-92.

[2] Zhou, J.; Chu, H.; Chan, J.F.; Yuen, K.Y. Middle East respiratory syndrome coronavirus infection: Virus-host cell interactions and implications on pathogenesis. Virol. J. 2015, vol.12, p.218.

[3] Chan, J.F.; Lau, S.K.; To, K.K.; Cheng, V.C.; Woo, P.C.; Yuen, K.Y. Middle East respiratory syndrome coronavirus: Another zoonotic betacoronavirus causing SARS-like disease. Clin. Microbiol. Rev. 2015, vol.28,p.465-522. [CrossRef] [PubMed]

[4] Carinci, F. Covid-19: Preparedness, decentralization, and the hunt for patient zero. BMJ 2020,p:368, bmj.m799. [CrossRef]

[5] Li, G.; Fan, Y.; Lai, Y.; Han, T.; Li, Z.; Zhou, P. et al. Coronavirus infections and immune responses. J. Med. Virol. 2020,vol.92,p.424-432. [CrossRef]

[6] Muniyappa, R.; Gubbi, S. COVID-19 Pandemic, Corona Viruses, and Diabetes Mellitus. Am. J. Physiol. Endocrinol. Metab. 2020,vol.318: E736-E741.

[7] Murillo, A.; Vera-Estrella, R.; Barkla, B.J.; Mendez, E.; Arias, C.F. Identification of Host Cell Factors Associated with Astrovirus Replication in Caco-2 Cells. J. Virol. 2015, vol.89, p.10359-370. [CrossRef]

[8] Sorokin AV, Karathanasis SK, Yang ZH, Freeman L, Kotani K, Remaley AT. Covid-19associated dyslipidemia: implications for the mechanism of impaired resolution and novel therapeutic approaches. Faseb J. 2020. The FASEB Journal. 2020,p.1-11.doi: 10.1096/fj.202001451. [Epub ahead of print]. 
[9] Zheng Z, Peng F, Xu B, Zhao J, Liu H, Peng J, et al. Risk factors of critical \& mortal COVID19 cases: a systematic literature review and meta-analysis. J Infect 2020:81,p.e16e25.https://doi.org/10.1016/j.jinf.2020.04.021.

[10] Choi GJ, Kim HM, Kang H. The potential role of dyslipidemia in covid-19 severity: an umbrella review of systematic reviews. J Lipid and Atherosclerosis 2020;vol.9. https://doi.org/10.12997/jla.2020.9.3.435.

[11] Hariyanto TI, Kurniawan A. Dyslipidemia is associated with severe coronavi- rus disease 2019 (COVID-19) infection. Diabetes and Metabolic Syndrome: Clin Res Rev 2020;vo.14.p:1-8. https://doi.org/10.1016/j.dsx.2020.07.054.

[12] Abu-Farha M, Thanaraj T, Qaddoumi MG, Hashem A. Abubaker J1, Al-Mulla F The Role of Lipid Metabolism in COVID-19 Virus Infection and as a Drug Target. Int. J. Mol. Sci. 2020, vol.21, no.3544;p.1-11. doi:10.3390/ijms21103544

[13] Deng, S.Q.; Peng, H.J. Characteristics of and Public Health Responses to the Coronavirus Disease 2019 Outbreak in China. J. Clin. Med. 2020,vol.9,n0. 575,p.1-10.

[14] Taube, S.; Jiang, M.; Wobus, C.E. Glycosphingolipids as receptors for non-enveloped viruses. Viruses 2010, vol.2,p. 1011-49

[15] Ono, A.; Ablan, S.D.; Lockett, S.J.; Nagashima, K.; Freed, E.O. Phosphatidylinositol $(4,5)$ bisphosphate regulates HIV-1 Gag targeting to the plasma membrane. Proc. Natl. Acad. Sci. USA 2004, vol,101,p.1488-9

[16] Zhang, J.; Pekosz, A.; Lamb, R.A. Influenza virus assembly and lipid raft microdomains: A role for the cytoplasmic tails of the spike glycoproteins. J. Virol. 2000, vol.74, p.463444. [CrossRef] [PubMed] 